\title{
Losers' Second Chances and Control of the Party Machine: Aspirant Premiers in Regional Spain
}

\author{
Javier Astudillo \\ Draft version: version March 2015
}

In parliamentary democracies controlling party machines has traditionally been a key asset for nascent political leaders to continue in their position if they have suffered a bad electoral start. Recent proposals suggest, however, that this is no longer the case in 'old democracies', but the extent of its continuing importance in 'young' ones is still unclear. Based on a dataset built by the author of the candidates from the main national parties for the premiership of the Spanish Comunidades Autónomas, we have analyzed if being party chair increases their chances of 'reselection' after losing their first elections. We conclude that in Spain, our example of a 'young' democracy, party machines still play a fundamental role for starting as a political leader.

Keywords: Presidentialisation of elections; party machines; top candidate selection; political leaders; young democracies; regional elections

What assets do nascent political leaders that lose their first elections need to control if they want to repeat the experience of throwing their hat into the electoral ring? In an alleged time of parties' internal transformation, does controlling their machines still protect politicians in the face of electoral setbacks?

Politicians need to attain the highest executive offices to lead. In most democracies this means that parties must have previously selected them as their candidates for those offices. Furthermore, if they lose the elections, and wish to run again, they must be reselected as candidates. Party intervention in their reselection or replacement is thus a vital part of the game.

In Western parliamentary politics, this remains an understudied topic. So far, studies about reselection have focused on incumbents (Wayne \& Baker 1986; Fisher III \& 
Herrick 2002). A few scholars have analyzed losers' fate (Taylor \& Boatright 2005; Carsey \& Berry 2014), but they have exclusively focused on US legislative candidates, where party machines have tended to play a lesser role in candidate recruitment. With respect to 'executive candidates' in parliamentary democracies, we only have the recent proposition that the new criteria used by parties for the selection of political leaders can make them less 'durable' in the face of electoral defeats (Webb, Poguntke \& Kolodny 2011). It is not clear, however, if in some parties, especially those in 'young democracies', control of the party machine can still protect nascent political leaders from the repercussions of a bad start in the electoral arena.

This paper attempts to assess the current salience of chairing the so-called "party central office' - the governing body of the extra-parliamentary party machine (Katz \& Mair 2002)- for top candidates' renomination after losing their first elections at the regional level in Spain. By doing so, it seeks to evaluate to what extent we can generalise the alleged decline in the relevance of party machines for top candidate recruitment and replacement processes in 'old parliamentary democracies' to 'young' ones, and what the consequences are for political leaders at a crucial moment in their careers.

In the next section we discuss the arguments about the alleged loss of salience of the party organisation on politicians' selection and replacement as top candidates, and why we focus on the Spanish Comunidades Autónomas. In section three we explore the meaning of 'losing' an election in parliamentary democracies. In section four we present the basic descriptive information about the top regional candidates in Spain. In section five we present our main hypothesis, the salience of being party chair, and other control variables. Following that, we offer the results of our empirical analysis. The final section concludes.

\section{The Alleged Declining Role of Party Machines in the Reselection of Nascent Political Leaders}

The literature about 'political leadership' tends to focus on the heads of the executives, presidents or prime ministers. These studies have shown that political parties are a fundamental factor in political leaders' capacity to carry out their policy preferences (Elgie 1995). A head of government who does not count on the collaboration of the 
legislature cannot implement his or her policies. Parties have traditionally been one of the most important instruments for obtaining this collaboration.

The important role that political parties play does not start, however, when political leaders become chief executives, but in their very recruitment. In a democracy chief executive offices are directly or indirectly 'elected'. This means that prospective political leaders must not only win their elections, but in most countries they must have previously been selected as candidates by the political parties. And if after losing elections they wish to run again, they must be reselected by the party. If not, a promising executive political career can end at its very start. The role that political parties play in executive candidate selection and replacement therefore seems to be a fundamental element in explaining the beginning of a top leadership career. However, its study needs further research, especially in parliamentary democracies (Helms 2005).

The multiple roles that parties play in the recruitment of legislative candidates in parliamentary countries are well established (Gallagher \& Marsh 1988; Norris 1997; Hazan \& Rahat 2010). We know that in these countries political parties have played a vital role not only because in most of these countries their machines controlled until recently the selection of candidates (Scarrow, Webb \& Farrell 2002), but because having a long record of voluntary work for the party organisation, or 'party service', was a requisite for selection (McAllister 1997). Through this process, elected officials were socialised into the party's culture and practices (Hazan \& Rahat 2010). We also know that legislators' loyalty to their parties was a key factor for reselection (Wessels 1997).

Less attention has been paid, however, to the recruitment of candidates for the head of the executive in parliamentary systems: the prime ministers. Some work has been done on the democratisation of the 'selectorate' of political leaders (Scarrow, Webb \& Farrell 2002). But, notwithstanding a few studies (Samuels \& Shugart 2010), we know much less about possible changes in the criteria parties use to select them, or in the salience of party machines in the reselection of those aspirants experiencing a bad electoral start.

A few studies approaching these topics suggest that recently, at least in the old parliamentary democracies, the role and salience of party machines in the reselection of political leaders has experienced profound transformation. This has come as a consequence of the combination of two contemporary processes: the 'presidentialisation' of parliamentary elections (Poguntke \& Webb 2005) and the 
increasing salience of the so-called 'party in public office' -the representatives of the party in parliament and government (Katz \& Mair 2002). If, as we will see, the first process, by triggering a change of parties recruitment criteria, increases the level of responsibility attached to these 'executive candidates' for parties' electoral results, its combination with the new salience of the party in public office has even deeper implications. Taken together it would lead to a loss of the protection that controlling the party machine offers political leaders experiencing electoral setbacks. Although these scholars mention political leaders' increasing vulnerability in general, we can think that this loss of resilience would be even bigger in the case of nascent political leaders. Contrary to veterans who suffer a defeat after winning previous elections, new ones still have to prove that they deserve the trust parties put on them when selecting as their candidates. However, as we will argue, it is far from clear to what extent we can generalise the transformation of parties' role for political leaders in general, and beginners in particular, to all kind of political parties and, above all, to all parliamentary democracies.

But before entering into the argument, we must first explain who we are referring to by 'executive candidates' in this kind of democracy, because in parliamentary elections, all 'candidates' are de jure 'legislative' candidates. In fact, in parliamentary democracies, by definition, there are no proper 'executive candidates' who run in any popular election. Prime ministers are selected by legislatures. Nevertheless most parties identify now their 'top candidate' in the electoral campaigns. They are usually their informal candidates for being prime minister. This process has been reinforced because the mass media has increasingly focused on these 'executive' candidates (Farrell \& Webb 2002).

The announcement of 'prime ministerial candidates' in what are still formally parliamentary elections is the first step of their 'presidentialisation', whose implications for citizens and parties' behaviour, or leaders' pathways to power and resilience are now starting to be analysed (Poguntke \& Webb 2005). Some debate to what extent citizens vote depending on whom parties present as 'top candidates' (Garzia 2012). Others focus on parties and political leaders. Webb, Poguntke \& Kolodny (2011) have proposed that this presidentialisation process also modifies the criteria that political parties use to select them.

In the heydays of mass party the last step of a politician's successful internal party career was usually obtaining the highest office of the extra-parliamentary organisation, 
the party chair, thanks to a meticulous process of building a power base within the organisation (Ware 1996). They were also offered as the party's aspirant for the prime minister office.

It is true that under the old recruitment criteria of political leaders parties risked supporting dull aspirants for the prime minister's office, expert only in winning negotiations in smoke-filled rooms. At a time when people voted for ideological or party attachment reasons, or parties were willing to sacrifice votes for ideological purity, this was not such a problem. However, 'mainstream' parties, after becoming catch-all parties, could no longer afford such selection criteria when winning elections became their paramount goal and the personal qualities of their now 'top candidates' started to be highly valued by citizens. As a result, according to Webb, Poguntke \& Kolodny (2011), parties now seek to select top candidates that they believe will give them the highest chances of winning the elections.

These changes in political leaders' selection criteria will have effects both on their partisan background, and on their durability in the face of a bad electoral performance. On one hand a long internal party career is no longer a requisite to be selected. In this vein, other scholars have even suggested there is an increasing selection of nonprofessional candidates (Dalton, Farrell \& McAllister 2011). On the other hand, Webb, Poguntke \& Kolodny (2011, p. 9) suggest that such leaders are 'less likely to survive electoral defeats than their precursors'.

These scholars offer a double reason for this loss of resilience. It is not only that if they lose, they have belied their parties' expectations of them. It is also the fact that, whereas aspirants for the prime minister office in the past were safely entrenched in their parties, they usually headed the extra-parliamentary organisation, the current ones, because of their limited party experience, no longer control the party arenas where dissatisfaction with 'their' electoral results is mounted. In brief, aspirants for the political leadership now no longer have to spend their energies in burdensome party work and climbing through the internal party offices, but at the cost of assuming a higher responsibility for their parties' electoral defeats.

We must note, however, that according to these scholars, a long internal party career is not necessary to be selected as top candidate. But this does not mean that having that party background is incompatible with being selected. We would thus expect that those current top candidates who by whatever reasons are still 'entrenched' in their parties, and have become party chair before getting their nomination, could control the post- 
election challenges to their leadership mounted by colleagues by using their internal party resources.

Things are not so simple, however, because in current parliamentary democracies the protection that controlling the party machine provides seems to be quite uncertain from a theoretical point of view. On one hand, as part of their argument about the 'cartelisation' of political parties, Katz and Mair (2002) have suggested that the increasing reliance of political parties on state resources has involved a shift in parties' internal distribution of power. The 'party in public office' has thus managed to subordinate the 'party's central office' because most of the state subsidies goes to the former. If this is so, the attributing of a higher level of responsibility to top candidates for their parties' electoral defeats happens precisely when a shift in the intra-party balance of power has deprived them of the utility of controlling the extra-parliamentary party organisation. Therefore losing top candidates that chair the party's central office may be just as vulnerable as those who do not if, for example, dissatisfaction with them appears among the parliamentary party.

On the other hand, Katz and Mair themselves did not expect the relegation of the party's central office to be universal. They expected this relegation to be more pronounced in the 'mainstream parties' than in the so-called 'fringe parties' because of the higher accessibility of the party in public office to state resources, and their officeseeking orientation. Similarly, Van Biezen (2000) has shown that in the so-called 'young democracies' of Southern and Eastern Europe the party's central office emerges 'as the most predominant' organ, which is reflected in the fact that the largest part of the state subventions is allocated to the extra-parliamentary organisation. This is so, she suggests, because, given weakly developed party loyalties and lack of party institutionalisation, political leaders in young parliamentary democracies use the extraparliamentary organisation to maintain unity within the party in public office. If true, then it is not clear whether controlling party machines will have lost its salience in these democracies, even if their parliamentary elections have been presidentialised and their mainstream parties, like their counterparts in 'old' democracies, have also had to introduce electoral concerns into their selection criteria. Consequently in the 'young democracies' we should expect that, ceteris paribus, current losing top candidates who are still the party chairs are more likely to repeat as candidates than those who do not hold that extra-parliamentary office. In addition, the salience of being party chair should 
be even bigger in the fringe parties than in their mainstream counterparts. Are these theoretical expectations correct?

In order to test these expectations, we focus on the candidates for the premiership of the 17 Spanish regional governments who were 'defeated', referred to here as 'losers'. In addition, we will study only 'first-time losers' (that is candidates who ran for an elective office for the first time, and lost) who were in opposition, because we are interested in assessing the salience of controlling party machines at a crucial moment in the careers of nascent political leaders.

Spain, one of the countries analyzed by Van Biezen, is a good case to study the current role of the party machine on losers' survival in 'young democracies'. First of all, the presidentialisation of its elections is said to have been present since reestablishment of parliamentary monarchy by the constitution of 1978 (Gunther, Montero, \& Botella 2004). Therefore we would expect Spanish parties to give high salience to whom they select as 'top candidate' ${ }^{1}$. Secondly, Spain is also interesting because its party system has been mainly composed in the last decades of two 'mainstream' national parties, the social democrat PSOE and the conservative Partido Popular (PP), who have alternated power since 1982, a smaller further-left coalition, Izquierda Unida (IU), and 'non-state wide parties'. Therefore, we can additionally check if there are differences between 'mainstream' and 'fringe parties' on the role of extra-parliamentary party organisations on losers' durability.

However, studying the national politics of just one country has an insurmountable limitation: we have more variables than cases. Fortunately, one of the recommended ways to increase the number of observations relevant to our theory is to study subnational units. By studying the regional level we can increase the number of observations while holding factors that vary across nations. Obviously, studying regional politics has its own implications that we will consider when accounting for losers' chances of renomination.

Before presenting the descriptive data about the top regional candidates in Spain, we must first address the question: what does 'losing an election' mean in a parliamentary system?

\section{Which Top Candidates are Regarded as 'Losers'?}


In presidential systems after the polls are closed and the votes are counted, it is (almost) certain who will become the next president and, therefore, which candidate has won the elections. In parliamentary systems, if when the polls are closed and votes are counted, no party, or pre-electoral coalition of parties, has obtained an absolute majority of legislators, it is just the beginning of the game. A top candidate can belong to the most voted party, with a plurality of MPs, and still be left in opposition.

So a first possible definition of a 'winner' (and therefore a 'loser') is a top candidate who becomes prime minister in the first government formed after the elections, regardless of whether or not $\mathrm{s} / \mathrm{he}$ is the candidate of the party who obtained the highest number of legislators. The rest are 'losers'.

Another feature of parliamentary systems, their collegial executives, makes things a bit more complex. Let us think about a real example taken from the Spanish regional elections. For the 2003 elections in the Comunidad Autónoma of Cantabria in Northern Spain, the regional branch of the Spanish socialists selected a new candidate, Lola Gorostiaga, for the regional premiership. The Socialist Party, except for a brief period at the beginning of the $90 \mathrm{~s}$, had never been in power in that region. After the elections, the PSOE finished, as usual, as the second most voted party. However, the most voted party - the PP - again failed to obtain an absolute majority. In the previous government, they had held the presidency in a coalition with the Cantabrian regionalists (PRC), the third largest party in the region in both votes and seats. This time Gorostiaga offered the regionalists the opportunity to preside over a coalition government with the Socialists. The PRC accepted her offer, and she became vice-premier of the new regional government. Can she be regarded as a 'loser'? We doubt it. Yet, according to our first definition she was.

In this example the PSOE successfully managed to enter the regional government. Should we then consider all candidates whose parties are not able to enter the government as 'losers'? Let us think, for a moment, about candidates without real expectations of becoming the next regional premier, and whose parties had no previous legislators in the regional assembly, but who manage to obtain a seat for themselves, and perhaps even for other colleagues. Are they going to be regarded as 'losers' by their own party? The appraisal they usually receive makes us doubt it. So from this perspective we could now consider all top candidates whose party enters the first government formed after the election as 'winners', or, if the party had never held legislative seats, those who managed to obtain their seat. The 'losers' will be the rest. 
Which definition of 'loser' is better? The first definition is perhaps too broad because, owing to the strict interpretation of who a winner is (just those who become premiers),-we risk considering as 'losers' candidates who were actually regarded as winners by their own parties, while our second definition of loser is perhaps too narrow, because with our lenient definition of who is a winner we risk ignoring candidates who were in fact regarded as losers by their parties. As a result, we must decide whether we prefer to accept the error of possibly including some winners within our losers' pool (type I), or the potential error of excluding some of the losers from our pool (type II). We choose to take a cautious stance here and avoid the type-I error. The second definition gives us the highest probability of studying only losers, at the risk of excluding some of them.

\section{The Selection of Regional Top Candidates in Spain}

Spain is composed of 17 Comunidades Autónomas (CAs), whose political structure is formally parliamentary. In each region the people directly elect an assembly that selects the regional government. But a 'presidentialised practice' has also been underlined at this level of government (Aja 1999).

The PSOE and the PP have dominated the regional party systems in most CAs. Approximately 77 per cent of all regional governments have been headed by a premier belonging to one of them. Both parties have also amassed around 65-75 per cent of the vote at the regional elections, whereas the average vote of IU at the regional elections has been around six per cent.

Regional institutions have also stimulated both the creation of regional branches of the national parties and the emergence of parties exclusively located in some regions. In the case of the national parties, their regional branches have their own organs of selfrule. The chairs of the extra-parliamentary organisation are formally elected by their respective regional congresses, but in the mainstream parties, the PP and the PSOE, their central organs closely monitor this process. The 'candidates' for the premiership of regional governments, are selected in a different process and normally by the regional extra-parliamentary organs, although the ones belonging to the PP and PSOE must receive the formal approval of the central party organs (Astudillo \& García-Guereta 2006; Méndez 2006). Finally, although since the late 90s, both the PSOE and IU 
provide in their statutes for party primaries to select the top candidate, their use in practical terms has been very limited (Barberà \& Rodríguez-Teruel 2012).

We have studied all the regional elections and the top candidates of these three national parties for each of the 17 CAs from the early 1980s up to $2012^{2}$. That means that we have 427 candidates, but only 243 different individuals because many of them run more than once (on average a candidate has run 1.8 times). Our dataset was built using information from a variety of sources: party and public websites, a review of the Spanish press, parties' internal documents, and scholarly books.

In order to have a better idea of who were these top candidates, we start by presenting their main characteristics at the time of their first contest.

[Table 1 here]

In table 1 we can see that they are not atypical. Like regional legislative candidates (Coller, Ferreria do Vale \& Meissner 2008; Oñate 2010), they are middle-aged men, born in the region, have been affiliated to their parties for around 15 years, and had public office experience of around 11 years. The vast majority of them were in opposition when running for their first time, and, as expected by Webb, Poguntke \& Kolodny (2011), a substantial amount of them were not party chair. We can also see that there are no significant differences between candidates who were party chair and those who were not, except in their party membership and their previous public office experience. As expected again, this experience is somehow lower among non party chair candidates.

We focus now on the electoral result of those first-timers who were in opposition. Table 2 shows the proportion of oppositional top candidates for each party that can be regarded to have lost their first contest according to the first and second definitions. We can see that using the second definition reduces in each party the proportion of their losers, but as we explained before it gives more guarantees that no 'winner' is included in our pool of losers. In any case, no matter the definition, in all parties most oppositional top candidates lost their first contest, although the proportion is always lower in the case of the mainstream parties.

[Table 2 here] 
We proceed now to study those first-time oppositional losers according to the second definition of losing. As we drop the losers of the most recent elections, since we do not know yet if they will repeat or not, we retain 158 cases. Table 3 shows that over 40 per cent of all of them repeated in the next election as top candidates. We are not studying a rare event.

[Table 3 here]

The descriptive data also show that the two mainstream parties, PSOE and PP, seem to present slightly different features in comparison with the 'fringe' party, IU. Again, as expected, the former tend to present a higher percentage of candidates who were not party chair (see table 1). However, we had expected that our mainstream parties, because they are more office-oriented, would get rid of their losers in a higher proportion than our fringe party. Table 3 shows this is not the case. Notwithstanding this, why do some of them repeat at least once and others do not? Does being party chair matter?

\section{Variables and Hypothesis}

\section{Main Variables}

Dependent variable: losers running again or not

Our dependent variable is whether an oppositional candidate for the premiership of the Spanish CAs who 'lost' his or her first contest repeats in the next regional elections as his or her party's candidate (coded 1$)$, or not ( coded 0$)$.

Main independent variable: being 'party chair'

Earlier we argued that in the case of a 'young democracy', such as Spain, we should find that those candidates who control the party's central office do have a higher probability of surviving an electoral defeat and repeat as a candidate. As a proxy for the 
control of this extra-parliamentary party organ we study if the candidate is the "party chair' or not at the moment of their first contest ${ }^{3}$. We expect therefore:

H1: losers are more likely to run again if they were party chair at the time of their first contest.

In our previous discussion, we also saw that controlling the party's central office may be less advantageous in the case of the mainstream parties than in 'fringe' parties. To test this expectation we have thus built a dummy to distinguish between the PP and the PSOE (coded 0), and the IU (coded 1), and studied an interaction effect between being party chair and the class of party.

H2: the effect of being party chair is stronger in 'fringe' parties than in 'mainstream' parties.

\section{Control Variables}

In our explanation of why electoral defeats may affect the chances of candidates being renominated, we have so far held two assumptions that are debatable: (1) that losers themselves will wish to run again, and that (2) they will have to confront other aspirants to the next nomination. These factors may not only influence losers' chances of repetition, but they may also be associated with our main independent variable. Yet our goal is not to fully explain losers' repetition in itself, but to control for other factors that may affect the relation between being party chair and running again.

We know that the first assumption - losers will want to try again - is debatable even for winners (Wolak 2007). Consequently, inspired by a common practice in the study of incumbents' retirement, we have controlled, first, for some personal characteristics such as 'political ambition' (Fowler 1996) ${ }^{4}$.

\section{Political ambition and office holding experience}


Running an electoral campaign is not an easy job. It requires a high level of commitment, and candidates must have a strong desire for the potential benefits they obtain through winning to compensate for these costs (Fowler 1996). As a result, those who possess a high degree of ambition will be more willing to repeat their contestation experience. In addition, the literature suggests that political ambition and office holding experience are linked (Taylor \& Boatright 2005). Consequently, we use as a proxy for political ambition the number of years between candidates holding their first elective office (at any level) and their first contest for executive public office. Our concrete expectation is:

H3: losers are more likely to repeat the higher the number of years they have held an elective office (at any level) at the time of their first contest.

The performance of the regional economy

In politicians' personal cost-benefit analysis on running, they can also gauge their chances of winning by judging how the context at the time of the next elections affects those chances (Wolak 2007) ${ }^{5}$. The suggestion is that a favourable context for incumbents reduces oppositional politicians' personal desire to compete, and in the case of previous losers to run again, whereas an unfavourable context for incumbents has the opposite effect.

Scholars have suggested that one of these contextual factors is, for example, the economic situation (Taylor \& Boatright 2005). The economic voting model suggests that governments are punished (or rewarded) for bad (or good) economic conditions at election time. However, the fact that we are dealing with a multilevel context may significantly alter how the economic voting model holds (Reif \& Schmitt 1980). This means that we have to specify the level of 'economic performance' that citizens will look at (regional or national), and which incumbents are held accountable (the national or the regional ones).

Several studies on this matter (Anderson 2006; Queralt 2012; León 2012) lead us to propose that for most Spanish regions the public will take into account the economic results at the regional level, but they will hold regional politicians that belong to the party of the national incumbents accountable for those economic results as a way of 
showing (dis)approval of the performance of the central government in a subnational election (Anderson 2006) ${ }^{6}$. This means that a deteriorating economy in the region would represent an unfavourable context for those regional losers who belong to a party that is in power at the national level, but favourable for those losers who belong to a party that is in opposition at that level. Here we use as a proxy, the evolution of regional unemployment rate, provided by the Instituto Nacional de Estadística, between losers' first elections and the following ones.

H4: the effect of the increase in regional unemployment reduces the likelihood of losers belonging to a party in power at the national level of running again, but increases the likelihood of losers who belong to a party in the national opposition doing so.

Party's electoral evolution under the loser

So far we have been assuming that, irrespective of a loser's desire to repeat or not, obtaining the following nomination will be a highly contested issue. That is why being party chair puts a candidate in a better position to defeat other aspirants to the party's nomination. However, parties may be so satisfied with the electoral results obtained under their 'losers' that nobody dares to challenge their nomination if they decide to run again.

The issue here is how parties gauge the impact of their candidates on the election results. Following the study by Andrews \& Jackman (2008), we suggest that parties look at their 'electoral growth'. That is, we compare a party's results with its losers, in time ' $t$ ', with previous results, in ' $t_{-1}$ ', obtained under a different candidate (keep in mind that we are studying only first-time losers). Their new top candidate has lost the elections, but with him/her the party has improved its results, and perhaps in the next election s/he will win. In addition, we do not look at absolute but relative increases. A five-point percentage increase involves quite a different relative growth when the previous vote share was five per cent than when it was 40 .

H5: losers are more likely to repeat the more positive, in relative terms, the electoral evolution of the party is under their candidacy. 


\section{Other control variables}

We have already stated that we are studying regional politics. This level of government can have additional peculiarities that we should take into account. For example, some of our parties have a multi-level structure with different degrees of 'self-rule' for their regional branches. In some parties, the regional organisation can be highly autonomous in selecting its candidates for regional premier. In others they may have to accept the 'suggestions' received from their national colleagues.

It is important to include this control variable in our model because it could explain the association between being party chair and loser repetition. When regional party branches' self-rule is low, regional losers' fate is decided by their national leaders, and perhaps they select their favourite 'henchmen' in the regions, first as chairmen of the party branch, and later as 'candidates' for the regional premiership. As a result, if national leaders want them to repeat, in spite of having lost, they will do so, not because they hold that party office, but because of their connection with the central party elite. However, it is not clear to us if, on average, national leaders will want their regional losers to repeat or not. That is why we do not have a predetermined average expectation.

In addition, given that there is no equivalent to a 'Regional Authority Index' (Hooghe, Marks, \& Schakel 2010) for political parties, we have used proxies. First, the regional institutional score for the 'self-rule' dimension at the time of a candidate's first election and second, we have included in the analysis whether the party of the regional candidate was in office at the national level. Being in the central government is usually presented as a factor that weakens regional branches of national parties and strengthens national leaders (Méndez 2006).

Finally, the political relevance of newly created regional institutions may not be clear for ambitious politicians, therefore if they lose they may prefer to spend their energies in more prestigious elected offices at other levels. If, in addition, the frequency of party chairs becoming the top candidate of the party varied through time, then this time effect could explain the association between being party chair and repeating. Because of this potential spurious association we have also introduced a two-period dummy variable to control for the consolidation of both the new regional institutions created after the return of democracy in Spain, as well as the party branches. The first period is from the first regional elections, held from the beginning of the 1980s, to the end of 1993 . The second period is from the beginning of 1994 until the regional elections in $2012^{7}$. 


\section{Empirical Findings}

To test the hypothesised relations, given that our dependent variable is binary (a loser repeats or does not), we conducted a logit model. As the residuals for all losers within a Comunidad Autónoma may be correlated with each other, and the variance of the residuals is likely not to be constant across CAs, we have used robust estimates of the standard errors, clustering by CA.

In addition, we have built two models. In the first one we wanted to see the effect of being party chair while holding constant the class of party. In the second model we include the interaction between being party chair and the class of party to assess if the effect of being party chair is stronger, weaker, or does not matter in the case of fringe parties compared to mainstream parties.

[Table 4 here]

The first model shows that, as suggested, heading the party organisation has a clear positive and significant effect on the likelihood of repeating in the following election. In order to have a more substantive idea of the results, we have calculated the predicted probabilities of repeating while being party chair or not while holding the rest of the variables at their means. In the first case the probability is 54 per cent, in the second case 24 per cent. Being party chair increases losers' probability of repeating by 30 percentage points.

The first model also shows that the relative evolution of the party under the loser's first contest and the time period also have a significant impact on losers chances of rerunning. As expected, the greater the electoral evolution (in relative terms), the higher the losers' chances of repeating. Under certain circumstances losers may not have to fight to get their renomination. If they lose, but the party is satisfied with them, they repeat at least a second time.

In addition, figure 1 shows the effect of parties' electoral evolution for losers under two situations: when they are party chair and when they are not. In both situations, the likelihood of repeating as top candidate increases as losers improve their parties' electoral results. But notice that the probability of repeating among those losers who are 
not party chair and improve electoral results by 25 per cent is more than ten points lower than the probability of those who are party chair, but reduce party results by 25 per cent. Holding their party top office clearly offers candidates some protection from bad electoral performance.

[Figure 1 here]

We can also see that top candidates that lose their first contest in the second time period also have a higher probability of repeating than those who lost when the regional institutions and party branches had just been created. As suggested, this may mean an increasing losers' interest in those new regional institutions.

The rest of control variables are not significant, however. These results show that the number of years in public office barely increases the chances of repetition, and the result is not statically significant. Perhaps this is not a very good proxy for political ambition, or perhaps our assumptions about the desire of continue in politics of amateur politics are simply wrong. Subsequent analyses should study this matter.

The economic context where the next elections take place does not seem to affect losers' chances of repetition either. Perhaps forces in different directions could cancel each other. On the one hand, an unfavourable context to win the elections can reduce the desire of a candidate that lost the previous elections to try again. On the other hand, in this context potential aspirants can reject running in order not to burn themselves, and parties can therefore try to convince previous losers to run again. Again more finegrained analysis should disentangle this.

We can also see that those losers who belong to regions with a higher level of selfrule do not have a higher probability of being reselected, nor do those whose national party colleagues are in opposition, that is to say under those conditions when it could be argued the regional branches are more independent from their central party. This result does not mean that the probability of regional losers repeating is independent of their national colleagues' wishes. But as we argued, it is not clear if, on average, national leaders will want them repeat or not. It will probably depend on a case by case basis.

Finally, the data also show that losers belonging to our fringe party (IU) have a lower probability of repeating than those who belong to our mainstream parties (PP and PSOE), although the difference is not statistically significant. We have already 
commented in table 3 that there are few differences among the three parties in their losers' rate of repetition as candidates.

However, the second model does show that the kind of party does matter, but in a way that goes against our initial expectation ${ }^{8}$. The effect of being party chair decreases when the party is 'fringe', not 'mainstream'. After calculating the predicted probabilities, being party chair in a mainstream party increases the probability of repeating by 40 percentage points in comparison with those who are not in the same kind of party, while for our 'fringe' party it is just a 7-point increase. A possible explanation is that in the young democracies the extra-parliamentary organs of mainstream parties have a greater access to state resources than their counterparts in fringe parties. As a result, party chairs of the mainstream parties have more resources available to overcome internal challenges than party chairs in fringe parties. This is not the situation in old democracies because these resources go to the party in public office (Katz \& Mair 2002), so party chairs of mainstream parties do not control a higher proportion of internal resources than their counterparts in fringe parties ${ }^{9}$.

\section{Conclusions}

In this paper we have studied the relationship between political parties and political leaders in a 'young democracy', Spain. In particular we have focused on the relationship during a crucial moment of their career, when they face the polls for their first time and lose. If they are not reselected, promising leadership careers can simply end at their very start. We already know that political parties play a vital role for incumbent political leaders to advance their policy agenda. However, we know less about their role in the incipient moments of their political leadership.

Some studies suggest that in old parliamentary democracies today's prospective political leaders are less likely to be able to continue if their parties lose their elections than at times in the past. This can be attributed to a lethal combination of two broad political transformations that have directly affected the role and salience of parties. The presidentialisation of elections has changed parties' selection criteria and, as a result, increased top candidates' assumption of responsibility for their parties' defeats precisely when the new salience of the 'party in public office' has deprived them of a resource, the control of the party extraparliamentary machines, to face potential challengers. 
However, although elections in young democracies, like those in older democracies, may have undergone processes of presidentialisation, the fact that the party central office is still a power centre in the former may suggest that its control is still an important asset for nascent political leaders. In addition, the effects of these transformations in elections and the rebalancing of power within parties should be felt more strongly in mainstream than in fringe parties. Despite the intuitive appeal, these propositions had not been empirically tested.

Using the top candidates for regional executive office in Spain as a case study, we tried to test them. We admit that we may have been very inclusive regarding which candidates are considered as 'winners'. However, this procedure gives us more guarantees that in our pool of 'losers' no candidate regarded as a 'winner' by his or her party is included.

Our results show with a high degree of confidence the salience of controlling the party machine in Spain. First-time oppositional losers who are party chair have a probability of running again around 30 percentage points higher than those who do not hold this party office. While it is true that improving parties' electoral results also helps their chances of rerunning, this does not diminish the salience of being party chair.

These results confirm other studies that showed how young democracies somehow differ in the processes of transformation of parties, electors and political leadership occurring in old democracies. There are few doubts that parties in young democracies are presidentialisating their parliamentary elections just like their counterparts in old democracies have been doing since the $60 \mathrm{~s}$ or $70 \mathrm{~s}$. However, asides from other differences related to their political culture or institutional architecture, this process is taking place within a different structure of political parties, in which party machines are still the power centre. The result is that in this kind of democracy we do not find that lethal combination of factors that incipient leaders face in old democracies.

Starting leaders in young democracies may indeed be held responsible by their parties for their electoral results just the same as their counterparts in old democracies are. But, by controlling the extraparliamentary organization, they are more able to overcome a bad electoral start, and manage to have at least a second chance to prove their ability to lead their parties to victory. They are more resilient, at least at their beginnings. That this is a positive thing for the political leadership of these countries is more debatable. On the one hand, this can mean that promising political leaders can 
survive fortuitous setbacks at their start. On the other hand this can also mean that it is harder for citizens to get rid of dull politicians through voting.

Finally, these results also show that young democracies may have an additional difference in comparison with old democracies. Contrary to the expectation in old democracies, we have found that being party chair matters less in the case of our 'fringe' party. This is probably a consequence of the fact that their extraparliamentary machines do not receive the amount of public resources that their mainstream counterparts do. If this is so, the study of fringe and mainstream parties should incorporate contextual factors such as the kind of democracy where they act.

Given the novelty of the topic, we do not claim to have settled the issue of under what conditions nascent political leaders repeat after losing their first elections in parliamentary democracies. We admit that the role of central party organs on their losers still needs much research. But we do not find reasons to think that the role of the parties' machine on losing top candidates' reselection at the national level should be smaller, on the contrary. This study is therefore a first step in the analysis of this crucial moment of their career, and in understanding how in some types of democracy and some types of party, controlling party machines still matters. 


\section{Tables and figures}

Table 1 Main Features of Regional Top Candidates Who Run for Their First Time

\begin{tabular}{|c|c|c|c|}
\hline & All & Party chair & $\begin{array}{c}\text { Not party } \\
\text { chair }\end{array}$ \\
\hline Men (\%) & 89.7 & 91.2 & 87.4 \\
\hline Born in the region (\%) & 77.4 & 78.2 & 76.9 \\
\hline Age (mean of years) & 44.4 & 43.3 & 46.3 \\
\hline Not affiliated to the party (\%) & 6.2 & 0.0 & 15.8 \\
\hline Years affiliated to their party (mean of years) & 15.0 & 15.6 & 13.6 \\
\hline Public office previous experience (\%) & 82.1 & 85.6 & 76.6 \\
\hline Years holding a public office (mean of years) & 11.0 & 11.0 & 10.9 \\
\hline First-timers already in government $(\%)^{1}$ & 7.4 & 6.8 & 8.4 \\
\hline Selection by primaries (\%) & 4.9 & 4.7 & 5.3 \\
\hline Party chair (\%) & 60.9 & - & - \\
\hline \multicolumn{2}{|l|}{ Party chair by parties } & - & - \\
\hline PP (\%) & 58.7 & - & - \\
\hline PSOE (\%) & & & \\
\hline IU (\%) & 54.5 & - & - \\
\hline & 68.1 & & \\
\hline$N$ & 243 & 148 & 95 \\
\hline
\end{tabular}

Source: dataset created by the author. ${ }^{1}$ Either as regional premier or regional minister. 
Table 2 Percentage of Oppositional Top Candidates from Each Party Who 'lost' Their First Elections According to the $1^{\text {st }}$ and $2^{\text {nd }}$ Definition of Losing (Absolute Number of Losers in Brackets)

\begin{tabular}{|c|c|c|}
\hline & $1^{\text {st }}$ Definition of 'losing' & $2^{\text {nd }}$ Definition of 'losing' \\
\hline \multirow[t]{2}{*}{ PP } & $74.6 \%$ & $69.0 \%$ \\
\hline & (53) & (49) \\
\hline \multirow[t]{2}{*}{ PSOE } & $77.8 \%$ & $73.0 \%$ \\
\hline & (49) & (46) \\
\hline \multirow[t]{2}{*}{ IU } & $100.0 \%$ & $87.8 \%$ \\
\hline & (90) & (79) \\
\hline Total & $85.7 \%$ & $77.7 \%$ \\
\hline (N) & (192) & (174) \\
\hline
\end{tabular}

Table 3 Percentage of First-Time, Oppositional Losers that Repeat as Top Candidate in the Next Election by Party (Absolute Number of Those Repeating and Not in Brackets)

\begin{tabular}{lccc}
\hline & Not repeat & Repeat & Total \\
\hline PP & $58.3 \%$ & $41.7 \%$ & $100 \%$ \\
PSOE & $(28)$ & $(20)$ & $(48)$ \\
& $55.0 \%$ & $45.0 \%$ & $100 \%$ \\
IU & $(22)$ & $(18)$ & $(40)$ \\
& $61.4 \%$ & $38.6 \%$ & $100 \%$ \\
\hline Total & $(43)$ & $(27)$ & $(70)$ \\
(N) & & & $100 \%$ \\
\hline
\end{tabular}

Source: dataset created by the author 
Table 4 Factors Explaining First-Time, Oppositional Loser's Running Again

\begin{tabular}{lll}
\hline & Model 1 & Model 2 \\
\hline Constant & Repeat vs not repeat & Repeat vs not repeat \\
Party-chair (dummy) & $4.247(3.549)$ & $5.294(3.663)$ \\
Age & $1.316(.391)^{* * *}$ & $1.852(.441)^{* * *}$ \\
Office holding experience & $-.043(.030)$ & $-.051(.030)$ \\
Party at national government (dummy) & $.018(.023)$ & $.021(.021)$ \\
Unemployment increase & $-.050(.501)$ & $-.183(.520)$ \\
$\quad$ Unemployment*Party at national government & $-.016(.033)$ & $-.019(.032)$ \\
Relative electoral growth & $-.063(.075)$ & $-.057(.084)$ \\
Degree of 'self-rule' of region & $.012(.005)^{* *}$ & $.012(.005)^{* *}$ \\
Class of party (dummy) & $-.440(.260)$ & $-.546(.274)^{* *}$ \\
Party-chair*kind of party & $-.419(.574)$ & $.685(.917)$ \\
Time period (dummy) & - & $-1.563(.775)^{* *}$ \\
\hline Pseudo R ${ }^{2}$ & $1.336(.672)^{* *}$ & $1.548(.671)^{* *}$ \\
N & .18 & .19 \\
\hline
\end{tabular}

Robust standard errors in parenthesis, ${ }^{* *} \mathrm{p}<.01,{ }^{*} \mathrm{p}<.05$ Party chair: chair (1), not (0); Party at central government: at central government (1), not (0); Class of party: fringe party (1), mainstream parties (0); Time period: 1980-1993 (0), 1994-2012 (1)

Graph 1 Predicted Probabilities of Reselection for Oppositional Top Candidates Losing their First Elections

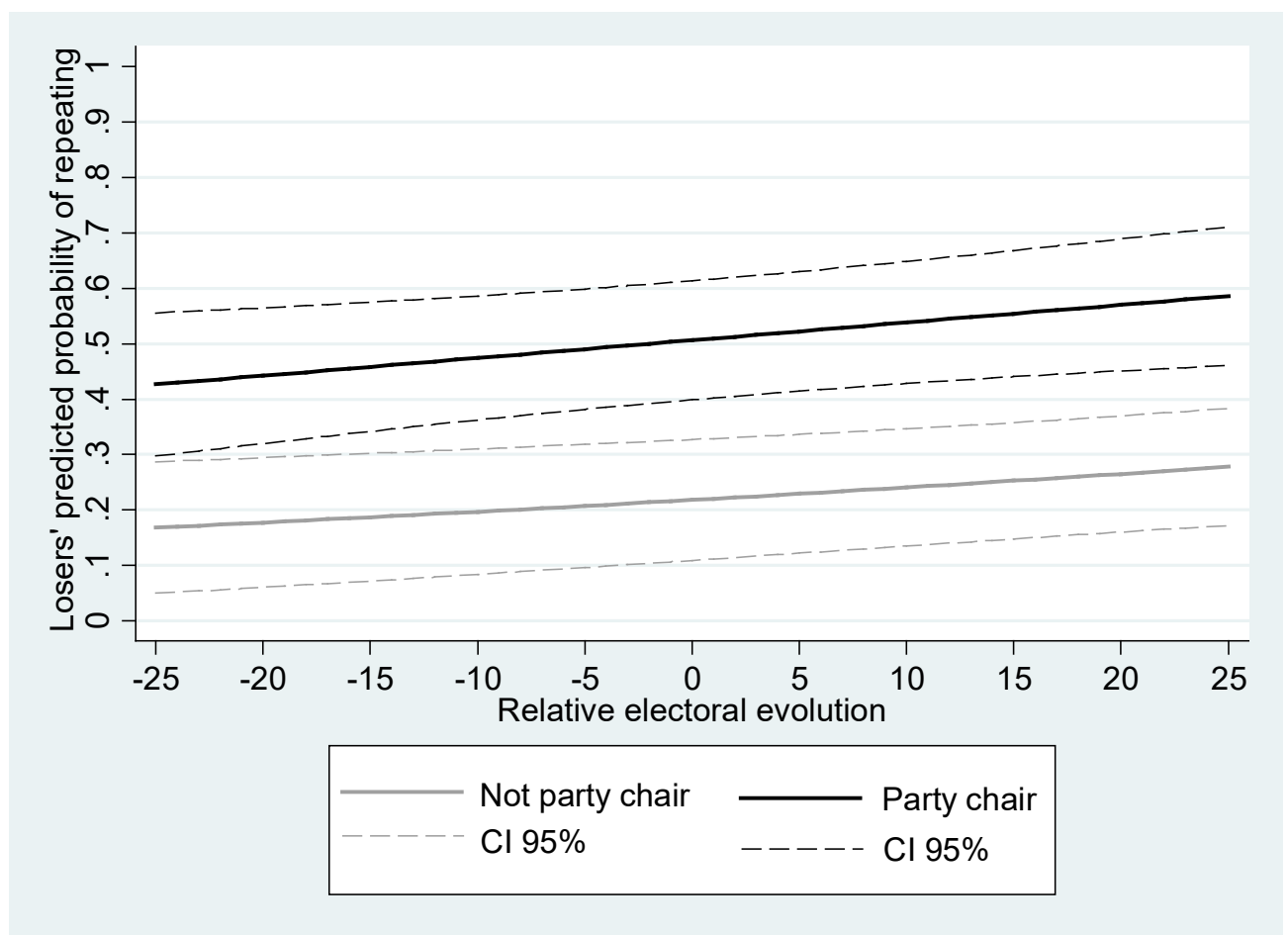




\section{Ackowledgments}

This study has been possible thanks to a research grant of the Instituto Carlos III-Juan March de Ciencias Sociales.

\section{References}

Aja, E. (1999) El Estado Autonómico, Alianza Editorial, Madrid.

Anderson, C. (2006) 'Economic voting and multilevel governance: a comparative individual-level analysis', American Journal of Political Science, vol. 50, no. 2, pp. 449-463.

Andrews, J. \& Jackman, R. (2008) 'If winning isn't everything, why do they keep score? Consequences of electoral performance for party leaders', British Journal of Political Science, vol 38, pp. 657-675.

Astudillo, J. \& García-Guereta, E. (2006) 'If it isn’t Broken, don't fix it: the Spanish Popular Party in power', South European Society and Politics, vol. 11, no. 3-4, pp. 399-417.

Barberà, O. \& Rodríguez-Teruel, J. (2012) 'The Introduction of Party Primaries in Spain', paper presented to the ECPR Joint Session, Antwerp, 11-15 April.

Carsey, T. \& Berry, W. (2014) 'What's a losing party to do? The calculus of contesting state legislative elections', Public Choice, vol. 160, pp. 251-273.

Coller, X., Ferreira do Vale, \& Meissner, C. (2008) 'Political Elites in Federalized Countries: the case of Spain (1980-2005)', ICPS, Working Paper, no. 268.

Dalton, R., Farrell, D. \& McAllister, I. (2011) Political Parties and Democratic Linkage, Oxford University Press, Oxford.

Elgie, R. (1995) Political Leadership in Liberal Democracies, St. Martin Press, New York.

Farrell, D. \& Webb, P. (2002) 'Political parties as campaign organizations', in Parties Without Partisans, eds D. Russell \& M. Wattenberg, Oxford University Press, Oxford, pp. 102-128.

Fisher III, S. \& Herrick, R. (2002) 'Whistle while you work: job satisfaction and retirement from the U.S. House', Legislative Studies Quarterly, vol. 27, pp. 445457. 
Fowler, L. (1996) 'Who runs for congress?', Political Science and Politics, vol. 29, no. 3, pp. 430-434.

Gallagher, M. \& Marsh, M. (ed) (1988) Candidate Selection in Comparative Perspective, Sage, London.

Garzia, D. (2012) 'Party and Leader Effects in Parliamentary Elections: Towards a Reassessment', Politics, vol. 32, no. 3, pp. 175-185.

Gunther, R. Montero, J.R. \& Botella, J. (2004) Democracy in Modern Spain, Yale University Press, New Haven.

Hazan, R. \& Rahat, G. (2010) Democracy within parties: candidate selection methods and their political consequences, Oxford University Press, Oxford.

Helms, L. (2005) Presidents, Prime Ministers and Chancellors: Executive Leadership in Western Democracies, Palgrave MacMillan, New York.

Hooghe, L. Marks, G. \& Schakel, A. (2010) The Rise of Regional Authority: a comparative study of 42 democracies, Routledge, London.

Katz, R. \& Mair, P. (2002) 'The ascendancy of party in public office: party organizational change in twentieth-century democracies', in Political Parties: Old concepts and new challenges, eds R. Gunther, J.R. Montero \& J. Linz, Oxford University Press, Oxford, pp. 113-135.

León, S. (2012) 'How do citizens attribute responsibility in multilevel states? Learning, biases and asymmetric federalism. Evidence from Spain', Electoral Studies, vol. 31, pp. $120-130$.

McAllister, I. (1997) 'Australia', in Passages to Power: Legislative Recruitment in Advanced Democracies, ed P. Norris, Cambridge University Press, Cambridge, pp. 15-32.

Méndez, M. (2006) 'Turning the page: crisis and transformation of the Spanish Socialist Party', South European Society and Politics, vol. 11, no. 3-4, pp. 419-437.

Norris, P. (ed) (1997) Passages to power: legislative recruitment in advanced democracies, Cambridge University Press, Cambridge.

Onate, P. (2010) 'The members of the Spanish autonomic parliaments: some features of a regional professionalized elite', Pôle Sud, vol. 33, pp. 27-46.

Poguntke, T. \& Webb, P. (ed) (2005) The Presidentialization of Politics: A comparative study of modern democracies, Oxford University Press, Oxford.

Queralt, D. (2012) 'Economic voting in multi-tiered polities', Electoral Studies, vol. 31, pp. 107-119. 
Reif, K. \& Schmitt, H. (1980) 'Nine second-order national elections: a conceptual framework for the analysis of European elections results', European Journal of Political Research, vol. 8, no. 1, pp. 3-44.

Samuels, D. \& Shugart M. (2010) Presidents, Parties and Prime Ministers: how the separation of powers affects party organization behaviour, Cambridge University Press, Cambridge.

Scarrow, S., Webb, P. \& Farrell, D. (2002) 'From social integration to electoral contestation: the changing distribution of power within political parties' in Parties Without Partisans: Political change in advanced industrial democracies, eds R. Dalton \& M. Wattenberg, Oxford University Press, Oxford, pp. 129-153.

Taylor, A. \& Boatright, R. (2005) 'The personal and the political in repeat congressional candidacies', Political Research Quarterly, vol. 58, no. 4, pp. 599607.

Van Biezen, I. (2000) 'On the internal balance of party power: party organizations in New Democracies', Party Politics, vol. 6, no. 4, pp. 395-417.

Ware, A. (1996) Political Parties and Party Systems, Oxford University Press, Oxford.

Wayne, L. F. \& Baker, J.R. (1986) 'Why do U.S. state legislators vacate their seats?, Legislative Studies Quarterly, vol. 11, pp. 119-126.

Webb, P., Poguntke, T. \& Kolodny, R. (2011) 'The presidentialization of party leadership?', paper presented at the American Political Science Association, Seattle, September 2011.

Wessels, B. (1997) 'Germany' in Passages to Power: Legislative Recruitment in Advanced Democracies, ed P. Norris, Cambridge University Press, Cambridge, pp. $15-32$.

Wolak, J. (2007) 'Strategic retirements: the influence of public preferences on voluntary departures from congress', Legislative Studies Quarterly, vol. 32, no. 2, pp. 285308 .

\footnotetext{
1 The Spanish press has thus reported that the main parties use internal surveys about potential candidates' electoral appeal in their selection process for the regional elections ( $A B C 27$ June 2002; $E l$ Mundo 10 August 2010).

${ }^{2}$ We have excluded the 'non-state wide parties' parties because their absolute number of first-time oppositional losers is very low.

${ }^{3}$ It is true that this proxy can be problematic. Politicians who have just arrived in the party can be first selected as party chair, and immediately thereafter selected as top candidate. This is not common, however. According to our data, on average, those party chair that were selected as candidates had been affiliated to their parties for around 12 years before they climbed at the top of the organisation.
} 
${ }_{5}^{4}$ Following common practice we have also controlled for losers' age.

${ }^{5}$ It is true that losers' evaluation of trying a second time can be influenced by other options they have in politics and the private sector. However these other options they may have are difficult to be empirically discovered. Although we knew what losers did after not repeating, we would not know if obtaining another political office or job in the private sector was the cause (losers preferred those offices to rerunning) or the consequence of quitting (they got it as a 'consolation prize' from their parties).

${ }^{6}$ In Catalonia and the Basque Country the approval of the regional incumbent can also affect losers' costbenefit analysis (León 2012). We have rerun the analyses without these two CAs to see if their exclusion affects the test of this hypothesis. They do not.

${ }^{7} \mathrm{We}$ did not include a variable referring to how candidates are formally selected because there is almost no variation across time, regions and parties.

${ }^{8}$ In the second model, the higher the degree of regional 'self-rule', the lower the likelihood of repeating. This could mean that the intervention of national leaders can have a positive effect on losers' renomination, once we control for the effect of the being party chair depending on the type of party.

${ }^{9}$ We have also checked if these results varied according to the definition of 'loser' used. In the first model they do not, but in the second model the interaction effect between type of party and being party chair is not significant. However, according to the first definition all IU top candidates are 'losers' (see table 2) whereas probably some of them were regarded as 'winners'. 